УДК $343.3 / .7$

DOI https://doi.org/10.32837/yuv.v0i4.1986

О. Сікан,

аспірантка кафедри кримінального права

Національного університету «Одеська юридична академія»

\title{
ПЕРЕЛЮБ (АДЮЛЬТЕР) ЯК ЗЛОЧИН ПРОТИ СІМ'Ї
}

Шлюб і сім'я без перебільшення $€$ найважливішими 3 ціннісних надбань в історії людства, а культура й форми співжиття $€$ визначальними складовими частинами гармонійного й стабільного розвитку суспільства. 3 найдавніших часів, коли свобода статевих відносин була майже безмежною, на ряду з проявами проміскуїтету, гомосексуалізму, інцесту тощо зароджувалися ознаки моногаміi матримоніальних відносин і з'являлися обмеження щодо перелюбу (адюльтеру). Адюльтер - караний проступок, що неминуче тягнув за собою покарання, які залежно від формації, місця та часу їх застосування були різноманітними - від найсуворіших до більш-менш гуманних [1, с. 282]. В епоху постмодерну 3 характерним збільшенням плюралізму в суспільстві й загостренням багатоманітності розуміння моральності вкрай важливо приділяти увагу фундаментальним і системоутворювальним інститутам, щоб не допустити ї руйнації та забезпечити перспективи сталого суспільного розвитку. До таких базових інститутів із давніх часів належить сім'я, одним із руйнівних чинників якої $€$ перелюб (адюльтер, подружня зрада). Перелюб призводить до безповоротної руйнації взаємостосунків і є причиною та мотивом багатьох злочинів. Слід зауважити, що чинне кримінальне законодавство України не містить складу відповідного злочину, а латентність зазначеного діяння та відсутність офіційної статистики унеможливлюють оцінити нині дійсні масштаби наявної проблеми.
Загалом дослідження подружньої зради має багатоаспектний характер і відзначається плюралізмом підходів і думок. У науковій літературі зазначене діяння розглядається в рамках вивчення злочинів проти моральності [2, с. 107]. Історичні пам'ятки права свідчать про інтерпретацію перелюбу в контексті злочинів проти сім“і та неповнолітніх. У значній кількості країн заміжня жінка розглядалася як власність чоловіка й відповідно перелюбство було частково замахом на право власності й право на розмноження. Окремі експерти сучасності відносять перелюб до однієї з форм домашнього насильства [3]. Суспільна думка щодо морально-етичної оцінки подружньої зради також не єдина й та характеризується полярністю поглядів щодо необхідності встановлення кримінальної заборони за ї вчинення.

Постановка завдання. Враховуючи зазначене, вбачається за необхідне приділити увагу проблемним питанням криміналізації перелюбу (подружньої зради). Метою статті є виявлення історичних закономірностей криміналізації та декриміналізації такого діяння, як перелюб, у кримінальному праві України. Для досягнення поставленої мети були визначені такі завдання: встановити, коли вперше у вітчизняному кримінальному праві були передбачені правові санкції за перелюб; виявити хронологічну послідовність динаміки санкцій за зазначений злочин; встановити кореляції виявленого із сучасністю, обгрунтувати вплив подружньої зради 
на сімейні відносини й запропонувати відповідний механізм їх охорони від зазначеного суспільно-небезпечного діяння.

Дослідженням питань кримінальної відповідальності за перелюб приділяли увагу такі науковці минулого й сучасності, вітчизняні й зарубіжні вчені, як Ю. Аверкіна, Ж. Батай, Є. Беляєва, I. Бентам, Ч. Беккаріа, С. Бородіна, I. Галяутдін, Б. Гульбан, К. Джета, О. Зазимко, К. Леві-Стросс, О. Старко, Ш. Летурно, Г. Мальцев, Б. Малиновський, Дж. Мердок, Е. Побєгайло, K. Раєн, О. Сосновский, Я. Талалаж, І. Філановський, А. Шевчук, Д. Шестаков, Ю. Щербатих та інші.

Виклад основного матеріалу. Вивчення специфіки шлюбно-сімейних відносин дає можливість зрозуміти не лише суспільні, культурні, моральні цінності минулого, але й деякі закономірності сьогодення. На гендерні взаємини, сексуальну поведінку чинять вплив традиції національної культури, субкультурні фактори, релігія. У всі історичні епохи кожен із наявних класів мав свої власні гендерні інтереси. 3 цієї різноманітності інтересів завжди випливала різноманітність статевих стосунків, моральних поглядів і постулатів [4, с. 131].

Історично в багатьох культурах світу перелюб жорстоко карався, аж до страти [5].

Перші згадки щодо охорони шлюбно-сімейних відносин і покарання за перелюб містяться в найдавніших пам'ятках права. Більшість вчених-правознавців сходяться в думках про те, що першим джерелом права $€$ Старий Заповіт. Як найдавніше релігійне джерело, Старий Заповіт, що складається 35 книг (Буття, Вихід, Левіт, Числа, Повторення закону), містить у собі Закон Мойсея (Десять Заповідей або Десятислів'я, Декалог), який і став основою сучасної кримінальної галузі. Так, за старозавітним законодавством, грунтуючись на заповіді «Не чини перелюбу» (Вих. 20:14),
Закон накладав обмеження на всі види статевого зв'язку, крім законного (подружнього): «А коли хто підмовить дівчину, яка не заручена, й ляже 3 нею, то нехай дасть їй віно, й візьме їі собі за жінку» (Вих. 22:15). За статевий зв'язок із заміжньою жінкою та згвалтування призначалася найвища міра покарання - побиття камінням. Натомість за статеві зносини з рабинею, хоча й обрученою, смертна кара не призначалася (Лев. 19:20) [6, с. 59, 65].

Смертна кара дружинам за подружню зраду передбачалася Законами Ману в Стародавній Індії та законами Стародавнього Єгипту, Афін [7, с. 59, 65].

Засудження дружини до страти через удушення за перелюбство й подружню зраду передбачалося також за Законами Хамурапі [8, с. 59, 65].

Найсуворішому покаранню у вигляді смертної кари за перелюб піддавали й за законами Римської республіки. Ці злочини були в очах римлян досить тяжкими. Так, якщо чоловік застав дружину на місці злочину, то міг іiі вбити незалежно від того, чи був укладений шлюб cum manu чи sine manu [9, с. 136-142].

У багатьох юрисдикціях країн третього світу адюльтер, як і позашлюбне статеве життя (перелюб), досі переслідується законом. Там, де вони здійснюються, жінки караються набагато суворіше, ніж чоловіки, аж до забивання камінням. У деяких країнах світу випадками адюльтеру й перелюбства називають і ті випадки, коли жінку було згвалтовано. Так, наприклад, відбувається в Нігерії та Пакистані.

Подружню зраду нині заборонено шаріатом та ісламом, із цієї причини вона входить до переліку кримінальних злочинів в Ірані, Саудівській Аравіi, Афганістані, Бангладеш і Сомалі. Цікаво, що перелюб $є$ злочином у 21 американському штаті. У Брунеї подружня зрада й нині карається смертною карою. Лише три роки тому покарання за перелюб скасували 
в Південній Кореї [10] та нещодавно Конституційний суд Тайваню визнав, що подружня зрада не може вважатися кримінальним злочином, скасувавши статтю, що передбачала покарання за подружню зраду у вигляді до одного року позбавлення волі [11].

Урядом В'єтнаму ж, навпаки, майже десятиліття потому за адюльтер було запроваджено систему штрафів, а якщо такі стосунки спричинили «серйозні наслідки», то невірних чоловіка або дружина підлягають кримінальній відповідальності [12].

Історія мала й період, коли за подружню зраду покарання було мінімальним із відлученням від церкви, кари голодом, висміюванням тощо [13, с. 128].

Дослідження генези становлення кримінальної відповідальності за перелюб у пам'ятках права, які діяли раніше на території сучасної України, свідчить, що позашлюбні сексуальні стосунки раніше визнавалися за злочин, виключно підсудний церковному суду [14, с. 107]. 3 запровадженням християнства в Київській Русі почався відчутний вплив клерикального соціального контролю: церква керувала суспільством не меншою, а нерідко більшою мірою, ніж державна влада й місцеве самоврядування. Статут князя Ярослава Володимировича був відбиттям спроб церкви позбутися пережитків язичництва в сімейно-шлюбній сфері відносин.

Довгий час ці злочини були виключною юрисдикцією церкви й не були представлені у світському праві аж до 1588 р. на Правобережній Україні й аж до 1669 р. на Лівобережній Україні.

Уперше кримінально-правова охорона моральностіуВеликомукнязівстві Литовському виникає в Литовському статуті 1588 р., у розділі чотирнадцятому, котрий називався «Про злодійство всякого стану», де передбачалися три норми (артикули 29, 30, 31 ). Нормами передбачалися дуже суворі санкції за зваблення чужої дружини, водночас каралася й сама жінка, за подружню зраду (чужолозтво) й за звідництво. Вважається, що поява цих норм була результатом зміцнення світської влади, оскільки раніше покарання за означені діяння знаходилися цілком у межах церковної влади [15, с. 345-346, с. 520-521].

Наступною правовою пам'яткою, в якій містилися санкції за злочини проти моральності, був Артикул Військовий від 30 березня 1716 р., який містив переважно норми кримінального права. У главі XX цього Артикулу, яка називалася «Про содомський гріх, про насилля та блуд» передбачалася низка статей, в яких йшлося про злочини проти моральності. У цей же період з'являються «Права, за якими судиться малоросійський народ» 1743 р. За високою юридичною технікою «Права...» є однією 3 найцінніших пам'яток української правової культури XVIII ст. Хоча Кодекс і не набув офіційної чинності, п’ятнадцятирічна праця українських правників мала позитивний вплив на подальший розвиток українського правознавства. У цьому Кодексі передбачалися злочини, спрямовані проти моральності. Ці злочини каралися смертю через утинання голови, биттям публічно різками або канчуками, арештом і грошовою покутою, утинанням носа або вуха, биттям різками в стовпа публічно або вигнанням із міста (так само як і в Литовському статуті 1588 р.) [16, с. $682-695$, с. $164-166]$.

Крім того, XVIII ст. на українських землях позначилося ще й особливостями козацької кримінально-звичаєвої юстиції. Не були виключенням і злочини, які можна було на той час вважати злочинами проти моральності. Санкції за ці злочини були традиційно суворими. За перелюбство, содомський гріх передбачалося тілесне покарання. Винних били киями (дубовими палками) або батогами.

Джерелами кримінального права в Україні на початку XIX століття були третій Статут і норми магдебурзького права, а з 1840 року - 
15-й том Зводу Законів Російської імперії та прийняте в 1845 році «Уложение о наказаниях уголовных и исправительных» $[17$, с. 254]. Саме під час підготовки «Уложения о наказаниях уголовных и исправительных» отримали розвиток норми, спрямовані на захист сім’ї та неповнолітніх, і було визнано доречним присвятити вказаним діянням окремий розділ «О преступлениях против прав семейных», який містив у собі декілька глав. Так, до першої глави Уложення - «О преступлениях против союза брачного» було, зокрема, включено статтю, що передбачала відповідальність за подружню зраду [18].

Суворі покарання та розправа над порушниками за перелюб також регулювалися Магдебурзьким правом, яке, зокрема, дозволяло чинити самосуд чоловікам, якщо вони застали дружину з іншим чоловіком - в такому випадку цього чоловіка можна було поранити чи навіть вбити [19].

Друга половина XIX ст. у Російській імперії характеризується порівняно не суворими санкціями за ці злочини, натомість водночас кримінальне законодавство Австро-Угорщини демонструвало суворіше ставлення до означених злочинів із боку виду й розміру санкцій.

Радянське кримінальне законодавство взагалі відмовилося від криміналізації досліджуваного діяння та не виділяло самостійного розділу в Особливій частині Кримінального кодексу Української РСР, що зумовлювалося вимогами суспільно-політичного ладу тих часів і поширенням атеїстичної ідеології марксизму. Відповідні тенденції збереглися і під час прийняття чинного кримінального законодавства України.

Отже, історіографія питання свідчить про постійну увагу до проблем перелюбу від найдавніших часів і до сучасності.

Зважаючи на відсутність в національному законодавстві України кримінально-правової заборони щодо перелюбу й враховуючи відносну поширеність серед злочинів подружніх вбивств, важливим представляється питання визначення подружньої зради як мотиву й детермінанти їхнього вчинення.

Також проблемним питанням виділяють кваліфікацію вбивств через ревнощі, які вчинені в стані сильного душевного хвилювання. Зокрема, складно визначити факт зради як тяжку образу, що лежить в основі виникнення фізіологічного афекту.

Так, деякі вчені розглядають факт подружньої зради в усіх без винятку випадках як тяжку образу. Наприклад, Є. Побєгайло також підтримує цю думку, адже саме так зрада сприймається більшістю людей [20, с. 130].

Інші вчені дотримуються супротивної думки, зокрема А. Піонтковський зазначає, що зраду одного з подружжя судова практика не вважає тяжкою образою. Вбивство за такої умови слід вважати кваліфікованим [21, с. 22].

Зрада одного з подружжя не є приниженням честі й гідності іншого, тому не може розглядатись як образа, вважають М. Загородніков, В. Бєляєв і М. Свідлов [22, с. 142; 23, с. 47].

С. Бородін зазначає, що відповісти на запитання про визнання образи тяжкою в разі порушення подружньої вірності в присутності одного 3 подружжя заздалегідь для усіх випадків неможливо [24, с. 106].

На думку О. Старко, не завжди подружня зрада або зрада закоханих грубо принижує честь і гідність особи, яку зрадили, чи характеризується виключним цинізмом. У більшості випадків, зраджуючи, особа не має переважного прагнення глибоко принизити свого партнера, його честь і гідність. Тяжкої образи невірність набуває тоді, коли зрада, наприклад, систематична, демонстративна, супроводжується цинічними діями тощо [25, с. 499].

Проблемне й розмежування вбивств із мотивів помсти й вбивств із мотивів ревнощів. 
Так, помстою є дії, що спричиняють шкоду, мета яких - покарати особу чи декількох осіб у відповідь на справжню або уявну образу, несправедливість, насильство й таке інше, вчинені раніше.

Природа ревнощів як мотиву злочину подібна природі перешкоджання догляду партнера й має у своїй основі незадоволену потребу у володінні конкретною людиною, чоловіком або дружиною.

У науковій літературі зустрічається така думка, що мотив помсти поглинає мотив ревнощів. Однак це не завжди так, оскільки не в кожному випадку ревнощі $€$ приводом для виникнення помсти. Мета помсти виникає дещо пізніше в результаті зробленої людиною «внутрішньої роботи» Й прийняття рішення про засоби, за допомогою яких можна буде розв'язати таку конфліктну ситуацію. Таким чином, ревнощі є мотивом невпевненості в монопольному володінні людиною, а помста є метою покарання за таку неприпустиму, на думку злочинця, поведінку.

Отже, мотив у подружніх злочинах $€$ визначальним і характеризується наявністю міжособистісного зв'язку. Виникнення в одного з подружжя спонукання до вчинення злочину щодо іншого в більшості випадків $€$ результатом складного процесу сімейного спілкування, негативні сторони якого, проходячи через психіку певним чином, відбиваються в ній у вигляді мотиву суспільно небезпечного діяння. В умовах подружнього конфлікту, що передує злочину, мотивування залежить від складності й суперечливості міжособистісних відносин суб'єкта та їх фіксації в його поведінці [26, с. 101].

Дискурс щодо криміналізації перелюбу в умовах сьогодення набуває все більшої актуальності. В аспекті зумовленості кримінально-правової заборони перелюбу слушною представляється позиція О. Коробєєва стосовно того, що незахищеність певних суспільних відносин кримінально-правовими засобами на тлі заподіяної реальної їм шкоди нерідко спонукає людину до пошуку не передбачених законом альтернатив. Водночас наявна так звана криміналізаційна надмірність - перенасиченість законодавства кримінально правовими заборонами, потреба в яких уже відпала або не існувала зовсім. 3 огляду на це, під час криміналізації та декриміналізації діянь необхідне глибоке й всебічне вивчення соціальних реалій та їх адекватне відбиття в кримінальних законах [27, с. 8].

Враховуючи зазначене й зважаючи на збільшення злочинів, детермінованих перелюбом, слід зауважити, що перелюб потребує криміналізації як суспільно небезпечне й деструктивне явище. Умовами встановлення кримінальної заборони $€$ настання суспільно небезпечних наслідків і підвищений ступінь суспільної небезпеки у зв'язку з тим, що детермінує низку похідних злочинів у сімейній сфері, спричиняючи підвищену небезпеку відповідним суспільним відносинам.

Висновки. Отже, дослідження свідчить, що в різні історичні періоди приділялася увага й вводилися обмеження щодо заборони перелюбу. Відповідні норми містилися у всіх пам'ятках права минулих літ. Тривалий час через різні об'єктивні й суб'єктивні причини шлюбно-сімейні відносини довго залишалися поза фаховими інтересами дослідників. Проте вивчення специфіки шлюбно-сімейних відносин дає можливість зрозуміти не лише суспільні, культурні, моральні цінності минулого, але й деякі закономірності сьогодення. За весь період охоплення дослідженням спостерігається диференціація покарань за перелюб від суворих смертних кар до помірних грошових стягнень. Дослідження правових пам'яток дає можливість зробити висновок, що з $\mathrm{X}$ по $\mathrm{XX}$ століття вплив церкви на злочинність і караність діянь проти сім'ї був безпрецедентний. Згодом на питання 
декриміналізації багатьох злочинів проти сім’ї та моральності, в тому числі й подружню зраду, вплинули процеси секуляризації, які були продиктовані змінами суспільно-політичного устрою на початку XX століття.

Слід зазначити, що в більшості випадків ознаки перелюбу не беруть до уваги й не враховують під час здійснення кримінально-правої оцінки обставин справи, залишаючи за межами складів, що призводить до невірної кваліфікації та неналежної охорони відповідних суспільних відносин.

Сьогодення потребує перегляду підходів до розв'язання проблем, пов'язаних зі злочинним впливом на основи суспільного устрою та базові сімейні цінності, саме тому вважається необхідним повернутися до питання встановлення кримінальної заборони на вчинення перелюбу, криміналізувавши подружню зраду, й на основі родового об'єкта виділити окремий розділ в Особливій частині кримінального права «Злочини проти сім’”̈» та включити до нього склад злочину «подружня зрада».

У статті досліджено питання кримінальної відповідальності за перелюб (адюльтер). Приділено увагу історичним аспектам $i$ вивчено наявний міжнароднии досвід правового регулювання та охорони відповідних суспільних відносин. Для виявлення історичних закономірностей криміналізаціі та декриміналізації такого діяння, як перелюб, в кримінальному праві України були визначені такі завдання: встановити, коли вперше у вітчизняному кримінальному праві були передбачені правові санкиї за перелюб; виявити хронологічну послідовність динаміки санкиій за зазначений злочин; встановити кореляиіі виявленого із сучасністю, обтрунтувати вплив подружньої зради на сімейні відносини й запропонувати відповідний механізм їхньої охорони від зазначеного суспільно-небезпечного діяння. Встановлено, шо покарання за перелюб уже зустрічається в Старому Заповіті, який відносять до першоджерел найдавніших пам'яток права. Зазначено, що перелюб, як правило, лежить в основі багатьох злочинів, зокрема подружніх вбивств $i$ вбивств, мотивом до яких є ревнощі. Облрунтовано, щз подружня зрада спричиняе руйнівну шкоду сімейним відносинам, якіє надважливими для сталого розвитку суспільства й мають належним чином охоронятися з боку держави, а тому відповідні суспільно-небезпечні посягання потребують криміналізації. Наголошено, що кримінально караним перелюб має бути в разі настання суспільно-небезпечних наслідків, таких, як, наприклад, самогубство илена сім'і (дружини, чоловіка, сина, доньки тощо) або ж у разі втрати вагітності тощо. За ознаками родового об'єкта, що лежить в основі охоронюваних суспільних відносин, вбачається, що зазначений злочин сліо розмістити в окремому розділі Кримінального кодексу України «Злочини проти сім' $i »$. Видовим об'єктом подружньої зради виступають нематеріальні сімейні відносини. Суб'єктом перелюбу може бути як загальний, так і спеціальний суб'єкт.

Ключові слова: перелюб, адюльтер, подружня зрада, злочини проти сім’ї, ревнощі як мотив, подружні вбивства.

Sikan O. Fornication (adultery)
as a crime against family
The article examines the issue
of criminal liability for adultery
(adultery). Attention is paid
to historical aspects and the
existing international experience
of legal regulation and protection
of relevant public relations is
studied. To identify the historical


patterns of criminalization and decriminalization of such an act as adultery in the criminal law of Ukraine, the following tasks were identified: to establish when for the first time in domestic criminal law provided legal sanctions for adultery; identify the chronological sequence of the dynamics of sanctions for this crime; to establish correlations of the revealed with the present, to substantiate influence of marital infidelity on family relations and to offer the corresponding mechanism of their protection against the specified socially - dangerous act. It is established that the punishment for adultery is already found in the Old Testament, which is considered to be one of the oldest sources of ancient monuments of law. It is noted that adultery, as a rule, is the basis of many crimes, in particular, marital murder and murder motivated by jealousy. It is substantiated that adultery causes destructive damage to family relations, which are crucial for the sustainable development of society and should be properly protected by the state, and therefore the relevant socially dangerous encroachments need to be criminalized. It is emphasized that adultery should be criminally punishable in the event of socially dangerous consequences, such as the suicide of a family member (wife, husband, son, daughter, etc.) or in the event of loss of pregnancy, etc. According to the features of the generic object, which is the basis of protected public relations, it is seen that this crime should be placed in a separate section of the Criminal Code of Ukraine "Crimes against the family". Intangible family relationships are a specific object of adultery. The subject of adultery can be both a general and a special subject.

Key words: adultery, crimes against the family, jealousy as a motive, marital murder.

\section{Література}

1. Шевчук А.В. Перелюбство (адюльтер) - один із найдавніших злочинів статевої моралі. Право і суспільство. 2014. № 3. C. 279-284.

2. Макаров В.А. Генеза санкиій за злочини проти моральності в Кримінальному праві України. Право. 2013. № 4 (42). C. 107-111.

3. За подружню зраду - кримінальна відповідальність: юрист пояснила, як ие працює. 5.иа : вебсайm. URL: https:// www.5.ua/suspilstoo/za-podruzhniuzradu-kryminalna-vidpovidalnist-iurystpoiasnyla-iak-tse-pratsiuie-184843.html.

4. Кравещь В.П. Соціально-економічні передумови тендерної стратифікації первісного суспільства. Україна - Европа Cвіт : міннародний збірник наукових пращь. Тернопіль: ТНПУ ім. В. Гнатюка, 2013. C. 131-137.

5. Подружня зрада. Вікіпедія: вільна енциклопедія. URL: https: / / uk.wikipedia. org / wiki / \% D0\% 9F\% D0\% BE\% DO\% B4 $\%$ D $1 \% 80 \%$ D $1 \% 83 \%$ D0\% B6\% D0\% BD\% $D 1 \% 8 F \_\% D 0 \%$ B $7 \%$ D $1 \% 80 \%$ D0\% BO $\mathrm{D}$ $0 \% B 4 \% D 0 \% B O$.

6. Бабиніна К.С. Кримінальне право України в православному вимірі (стан, динаміка та перспективи) : дис. ... канд. юрид. наук: 12.00.08. Одеса, 2016. 216 c.

7. Супружеская измена. Википедия: свободная энииклопедия. URL: https: / / ru.wikipedia.org / wiki / \% D0\% A1\% D1\% 8 $3 \%$ D0\% BF\% D1\% $80 \%$ D $1 \% 83 \%$ D0\% B6\%

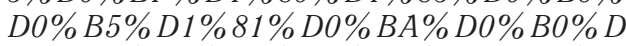
$1 \% 8 F \_\% D 0 \%$ B $8 \%$ DO $\%$ B $7 \%$ DO $\%$ BC $\%$ DO $\%$ B $5 \%$ DO $\%$ BD $\%$ DO $\%$ BO.

8. Казанник А.И. Наказание по Вавилонскому Талмуду. Вестник Омского университета. 1999. Bbın. 2. C. 156-158.

9. Казанцев Л.Н. О разводе по римскому праву в связи с историческими формами римского брака. Период языческий. Киев : Тип. Имп. ун-та св. Владимира, 1892. 247 c.

10. Секс із заміжньою жінкою більше не злочин: в Індї легалізували подружні зради. 112.uа : вебсайm. URL: https:// ua.112.ua/svit/seks-z-zamizhnoiuzhinkoiu-bilshe-ne-zlochyn-v-indiilehalizuvaly-podruzhni-zrady-463896.html.

11. На Тайвані скасували кримінальну відповідальність за подружню зраду. Zik: вебсайm. URL: https:// zik.ua/news/world/na_taivani_ skasuvaly_kryminalnu_vidpovidalnist_za_ podruzhniu_zradu_970250. 


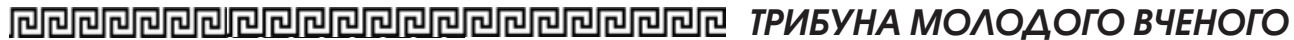

12. «Наліво» зі итрафом. Закон $i$ бізнес : вебсайm. URL: https: / / zib.com.ua/ ua/pda/45553.html.

13. Ивик Олег. История сексуальных запретов и предписаний. Москва : Ломоносовт, 2011. $288 \mathrm{c}$

14. Макаров В.А. Генеза санкиій за злочини проти моральності в Кримінальному праві України. Право. 2013. № 4 (42). C. 107-111.

15. Статути Великого князівства Литовського : у $3 \mathrm{~m}$. Статут Великого князівства Литовського 1588 р. : У 2 кн. Кн. 2 / за ред. С.В. Ківалова, П.П. Музиченка, А.Ы. Панькова. Одеса : Юридична rimepamyра, 2004. T. 3. 568 c.

16. Права, по которьмз судится малороссійскій народт 1743 г. Изг трехъ книг, изданныя подт редакиіею и съ приложениемг исследования о семг Своде и законахз действовавшихв в Малоросіи, профессора А.Ф. Кистяковского. Киев : Университетская типографія (I.I. Завадского), 1879. 944 c.

17. Музыченко П.П. История государства и права Украины в вопросах и отвеmax / П.П. Музыченко, Н.И. Долматова. Изд. 5-е. Харьков : Одиссей, 2007. Ч. 1. $254 \mathrm{c}$.

18. Шимановский B.M. Преступные деяния по Уложению о наказаниях уголовных и исправительных и Уставу о наказаниях, налагаемых Мировыми Судьями, статьям Уголовного уложения 1903 г. Одесса : Tuп. Аки. Южно-Рус. O-ва Печат. дела, 1910. 648 c.
19. Жернова Т.О. Як карали за любов, або пристрасті по-львівські. Фотографії старого Львова : вебсайm. URL: https: / / photo-lviv.in.ua/yak-karaly-za-lyubovabo-prystrasti-po-lvivsky/.

20. Побегайло Э.Ф. Умышленные убийства и борьба с ними: уголовно-правовое и криминологическое исследование. Воронеж : Изд-во Воронеж. ун-та, 1965. 206 c

21. Пионтковский А.А. Уголовное право. Особенная часть. Преступления против личности: учебное пособие для юридических институтов. Москва : Юрид. изд-во НКЮ СРСР, 1938. 136 с.

22. Загородников Н.И. Преступления против жизни по советскому уголовному праву. Москва :Госюриздат, 1961. 276 с.

23. Беляев В.Г., Свидлов Н.М. Вопросы квалификаичи убийств. Волгоград : ВСШ МВД СССР, 1984. $60 \mathrm{c}$.

24.Бородин С.В. Квалификация убийств по советскому уголовному праву : учебное пособие. Москва, 1963. $222 \mathrm{c}$

25. Старко О.Л. Деякі питання кваліфікаиіі вбивств, учинених на трунті ревношів. Держава $i$ право. 2010. № 47. C. 498-503.

26. Потильчак А.О. Мотивація подружніх вбивств. Юридичний вісник. Повітряне $i$ космічне право. 2011. № 4. C. 101-104.

27. Коробєев O.I. Кримінальний кодекс Росї: достоінства і недоліки. Юридичний Вісник України. 2006. № 19 (567). С. 8-9. 